Original Research Article

\title{
Assessment of Morus alba (Mulberry) leaves extract for anticonvulsant property in rats
}

\author{
Sriharsha Rayam, B. L. Kudagi*, Umer Sufyan M., Madhavulu Buchineni, \\ Rama Mohan Pathapati
}

Department of Pharmacology, Narayana Medical College, Nellore, Andhra Pradesh, India

Received: 10 December 2018

Accepted: 05 January 2019

\section{*Correspondence to:}

Dr. B. L. Kudagi,

Email: blkudagi@

rediffmail.com

Copyright: (C) the author(s), publisher and licensee Medip Academy. This is an openaccess article distributed under the terms of the Creative Commons Attribution NonCommercial License, which permits unrestricted noncommercial use, distribution, and reproduction in any medium, provided the original work is properly cited.

\begin{abstract}
Background: The mulberry tree, a plant of the family Moraceae and the genus Morus, has been widely cultivated to feed silkworms. Various parts of Morus alba linn used as an Anti-inflammatory, hypoglycemic, cardioprotective, hepatoprotective, free radical scavenging activity and neuroprotective agent. The plant contains flavonoids, moranoline, albanol, morusin coumarine, and stilbene, which have. In this study, anticonvulsant property of Morus alba leaves extract (MAE) was evaluated by using MES and PTZ induced convulsion in rats.

Methods: Effects of MAE were evaluated in experimental models of electro convulsions, maximal electro shock (MES) and chemoconvulsion induced by pentylenetetrazole (PTZ) in rats $(n=6)$, which were treated intraperitonially with doses of 100, 200 and $400 \mathrm{mg} / \mathrm{kg}$.

Results: The duration of tonic hind limb extension (seconds) with MAE in MES induced convulsions at dose of $100,200,400 \mathrm{mg} / \mathrm{kg}$ is $8.33 \pm 1.21$, $6.83 \pm 1.16 \& 3.16 \pm 0.98$ respectively. In the dose of $400 \mathrm{mg} / \mathrm{kg}$ of MAE showed highly significant results by reducing the duration of tonic hind limb extension in MES induced convulsions. And onset of jerky movements (seconds) with MAE in PTZ induced convulsions at dose of $100,200,400 \mathrm{mg} / \mathrm{kg}$ is $157.83 \pm 8.99,195.66 \pm 17.02$ and $295.50 \pm 21.10$ respectively. In the dose of $400 \mathrm{mg} / \mathrm{kg}$ of MAE showed highly significant results by delaying the onset of convulsions.
\end{abstract}

Conclusions: Results indicate that the MAE have anticonvulsant effects in MES induced convulsions and in PTZ induced convulsions.

Keywords: Anticonvulsant property, Intraperitoneally, Morus alba leaves extract, Maximal electro shock, Pentylenetetrazole

\section{INTRODUCTION}

India is one of the nations blessed with rich heritage of traditional medicinal system and rich biodiversity to complement the herbal needs of the treatment administered by these traditional medicinal systems.

A current estimates that, in many developing countries of the world, $80 \%$ population still they relay heavily on traditional healers and medicinal plants, for their primary health- care needs. ${ }^{1}$
The epilepsies are common and frequently devastating disorders, affecting $\sim 2.5$ million people in the U.S. alone. More than 40 distinct forms of epilepsy have been identified. Epileptic seizures often cause transient impairment of consciousness, leaving the individual at risk of bodily harm and often interfering with education and employment. Therapy is symptomatic in that available drugs inhibit seizures, but neither effective prophylaxis nor cure is available. Compliance with medication is a major problem because of the need for long-term therapy together with unwanted effects of many drugs. ${ }^{2}$ 
The mulberry tree, a plant of the family Moraceae and the genus Morus, has been widely cultivated to feed silkworms. Morus alba is a moderately sized tree, three to six metres high, native of India, China and Japan. This widely grown plant has been in use by tribals of this country for ailments such as asthma, cough, bronchitis, edema, insomnia, wound healing, diabetes, influenza, eye infections and nosebleeds. ${ }^{3}$ Morus alba leaves contain rutin, quercetin and apigenin as bioactive constituents. ${ }^{4}$ Many biochemical compounds such as moranoline, albafuran, albanol, morusin, kuwanol, calystegin and hydroxymoricin are isolated from mulberry plants which play an important role in pharmaceutical industry. ${ }^{5}$ The other uses of Morus alba are as a hypoglycemic, cardioprotective, and neuroprotective agent The mulberry fruit has been used as a medicinal agent to nourish the blood and for the treatment of weakness, fatigue, anemia, and premature graying of hair. In addition, some phenolic compounds from Morus alba have been reported to have antioxidant properties. ${ }^{6,7}$ The crude hydroalcoholic extract of Morus alba L. leaves was evaluated for hepatoprotection against hepatotoxicity induced by carbon tetrachloride. ${ }^{8}$ Anti-inflammatory activity is documented for mulberroside A and oxyresveratrol from the root bark of white mulberry in reducing carrageenininduced paw edema in rats. ${ }^{9}$ A piperidine alkaloid and some glycoproteins were isolated from the bark and leaves, which had antidiabetic effects. ${ }^{10}$

Taking this into consideration the reported psychopharmacological effects of Morus alba leaves in various animal models, ignited a spirit to evaluate antiepileptic activity of Morus alba leaves extract by maximal electro shock [MES] test and pentylenetetrazole induced convulsions in rats.

\section{METHODS}

\section{Animals}

This study was executed in the Department of Pharmacology, Narayana Medical College. The animals (Wister strain albino rats) weighing 150-200 mg were obtained from central animal house of Narayana Medical College, Nellore for all the animal experiments. They were housed in standard polypropylene cages. Colony breeds Albino rats of either sex weighing between 200250 gms were included in this study. The animals were excluded if the weight of rats was below $150 \mathrm{gms}$ and if they had any visible diseases. The animals were maintained under standard laboratory conditions (light period of $12 \mathrm{hrs} /$ day and temperature $250 \mathrm{C} \pm 10 \mathrm{C}$ ) with free access to food and water ad libitum. The animal experiments were approved by the IAEC (Institutional Animal Ethics Committee) with protocol number 27/2013/NMC, dated 20/12/2013.

\section{Plant material}

The mulberry leaves were collected from Udayagiri, Nellore district, Andhra Pradesh and the leaves were identified by Botanist Mr. K. Vishnu Vardhan, junior lecturer in botany, Govt. Junior College, Venkatagiri, Nellore district. The leaves were washed thoroughly under running tap water, shade dried for 5 days and ground to a fine powder in an electric mixer. The powder plant material was extracted twice with $90 \%$ ethanol at room temperature. Extracts were filtered with Whatman filter paper No.1. The filtrate was evaporated until dry, using a soxhlet evaporator, to obtain the extract. Before use, the extract was dissolved in distilled water for administration intaperitonially (i.p). ${ }^{11}$

Albino rats of male sex weighing from 200 to $250 \mathrm{~g}$ were used in this study. These were acclimatized to their environment for one week prior to experimentation. The animals were randomly distributed into five different groups. Each experimental group consisted of 6 animals. Each group was caged separately after recording its body weight and the animals were marked with marker for identification.

Two animal models were used to evaluate anticonvulsant effect of Morus alba leaves:

\section{Maximal electroshock [MES] induced convulsions ${ }^{12}$}

\section{Procedure}

MES seizures were electrically induced by means of an Electroconvulsiometer $150 \mathrm{~mA}$ current was delivered transauricularly via ear clips for $0.2 \mathrm{sec}$. Group of 6 rats will be pretreated with test drug $(100,200,400 \mathrm{mg} / \mathrm{kg})$, phenytoin $(25 \mathrm{mg} / \mathrm{kg}$, as standard), saline $(5 \mathrm{ml} / \mathrm{kg}$, as control) and after 30 min will receive the transauricular electroshock. The criterion for the anticonvulsant effect will be absence of tonic hind limb extension after delivery of the electroshock

\section{Pentylenetetrazole induced seizures ${ }^{12}$}

\section{Procedure}

Rats of male sex were divided into five groups; each group consisted of six rats. Rats were given pentylenetetrazole. Only those rats which produced jerky movements of the whole body were used for the study. After 30 mins of administering respective drugs to particular groups, Pentylenetetrazole was injected to the animals and the onset time for clonic convulsions are noted in all the groups. Later the onset time for clonic convulsions in all groups was compared. The onset time of clonic convulsions was taken as an end point.

\section{Statistical analysis}

The data were entered into excel spreadsheet 2007. Statistical analysis was performed using Sigma Graph pad prism version-6 USA. Data was described as Mean \pm Standard deviation. One way ANOVA followed by Post hoc Tukeys multiple Comparison tests was used 
for analysis of data among all groups. All the results of test drug (Morus alba) were compared with control and standard.

\section{RESULTS}

In MES induced convulsions test the duration of tonic hind limb extension (THE) for control group was $9 \pm 0.89$. For MAE the duration of THE in dose of $100 \mathrm{mg} / \mathrm{kg}$ was $8.33 \pm 1.21,200 \mathrm{mg} / \mathrm{kg}$ was $6.8 \pm 1.16$ and $400 \mathrm{mg} / \mathrm{kg}$ was $3.16 \pm 0.98$ respectively (Table 1 ) and (Figure 1 ). The tonic hind limb extension was highly significant $(\mathrm{p}<0.001)$ in standard group. Morus alba leaves extract in dose of 400 $\mathrm{mg} / \mathrm{kg} \quad(\mathrm{p}<0.001)$ showed highly significant results by reducing the duration of tonic hind limb extension compared to that of control, but less significant when compared to standard.

\section{Table 1: Maximal electro shock (MES) induced} convulsions.

\begin{tabular}{|l|l|}
\hline Group and dose (I.P) & $\begin{array}{l}\text { Duration of tonic hind } \\
\text { limb extension (THE) in } \\
\text { seconds in Mean } \pm \text { SD }\end{array}$ \\
\hline $\begin{array}{l}\text { Group-I: Control } \\
\text { Normal saline: } 0.5 \mathrm{ml} / \mathrm{kg}\end{array}$ & $9 \pm 0.89$ \\
\hline $\begin{array}{l}\text { Group-II: Standard } \\
\text { Phenytoin: } 25 \mathrm{mg} / \mathrm{kg}\end{array}$ & Totally abolished $* * *$ \\
\hline $\begin{array}{l}\text { Group-III } \\
\text { MAE: } 100 \mathrm{mg} / \mathrm{kg}\end{array}$ & $8.33 \pm 1.21$ \\
\hline $\begin{array}{l}\text { Group-IV } \\
\text { MAE: } 200 \mathrm{mg} / \mathrm{kg}\end{array}$ & $6.83 \pm 1.16 * *$ \\
\hline $\begin{array}{l}\text { Group-V } \\
\text { MAE: } 400 \mathrm{mg} / \mathrm{kg}\end{array}$ & $3.16 \pm 0.98 * * *$ \\
*p<0.05, **p $<0.01, * * * \mathrm{p}<0.001$ compared to control group. \\
$\begin{array}{l}\text { ANOVA followed by Tukeys multiple comparison tests was } \\
\text { used for analysis of data between the groups. }\end{array}$
\end{tabular}

Table 2: PTZ induced convulsions.

\begin{tabular}{|l|l|}
\hline Group and dose (I.P) & $\begin{array}{l}\text { Onset time of clonic } \\
\text { convulsion in seconds } \\
\text { Mean } \pm \text { SD }\end{array}$ \\
\hline $\begin{array}{l}\text { Group-I: Control } \\
\text { Normal saline: } 0.5 \mathrm{ml} / \mathrm{kg}\end{array}$ & $140.66 \pm 13.24$ \\
\hline $\begin{array}{l}\text { Group-II: Standard } \\
\text { Valproate }(\mathrm{SV}): 200 \mathrm{mg} / \mathrm{kg}\end{array}$ & $593 \pm 18.63 * * *$ \\
\hline $\begin{array}{l}\text { Group-III } \\
\text { MAE: } 100 \mathrm{mg} / \mathrm{kg}\end{array}$ & $157.83 \pm 8.99$ \\
\hline $\begin{array}{l}\text { Group-IV } \\
\text { MAE: } 200 \mathrm{mg} / \mathrm{kg}\end{array}$ & $195.66 \pm 17.02 * * *$ \\
\hline $\begin{array}{l}\text { Group-V } \\
\text { MAE: } 400 \mathrm{mg} / \mathrm{kg}\end{array}$ & $295.50 \pm 21.10 * * *$ \\
\hline *p<0.05, **p <0.01, *** p<0.001 compared to control group. \\
$\begin{array}{l}\text { ANOVA followed by Tukeys multiple comparison tests was } \\
\text { used for analysis of data between the groups. }\end{array}$
\end{tabular}

In pentylenetetrazol induced convulsions method the time of onset of clonus in control group was $140.66 \pm 13.24$. For sodium valproate the onset of clonus was $593 \pm 18.63$.
Onset of clonus for MAE at the dose of $100 \mathrm{mg} / \mathrm{kg}$ was $157.83 \pm 8.99$, for $200 \mathrm{mg} / \mathrm{kg}$ was $195.66 \pm 17.02$ and for $400 \mathrm{mg} / \mathrm{kg}$ was $295.50 \pm 21.10$ respectively (Table 2) and (Figure 2). When compared with control, sodium valproate showed highly significant $(\mathrm{p}<0.001)$ results and MAE in the dose of $200 \mathrm{mg} / \mathrm{kg}, 400 \mathrm{mg} / \mathrm{kg}$ showed highly significant $(p<0.001)$ results, but when compared to standard MAE $200 \mathrm{mg} / \mathrm{kg}, 400 \mathrm{mg} / \mathrm{kg}$ showed less significant results.

\section{DISCUSSION}

MES and PTZ tests provide some insight into the ability of a given drug to penetrate the blood-brain barrier and exert a central nervous system (CNS) effect. Both models are standard tests to evaluate antiepileptic activity in animal models therefore these are well suited for screening anticonvulsant activity of new compounds.

The maximal electroshock seizure test, in which tonic hind limb seizures were induced by bilateral transauricular electrical stimulation, was thought to be predictive of anticonvulsant drug efficacy against generalized tonic-clonic seizures. Morus alba extract $400 \mathrm{mg} / \mathrm{kg} \quad(\mathrm{p}<0.001)$ showed highly significant decrease in the duration of tonic hind limb extension compared to that of control. However when compared with standard (phenytoin) it showed less significant effect.

Gupta et al reported that methanolic extract in high doses $(100 \mathrm{mg} / \mathrm{kg})$ decreased the duration of tonic seizures and showed statistically significant anticonvulsant activity in the maximal electroshock test. ${ }^{13}$ The present study was in accordance with the above stated study with MAE at doses of $400 \mathrm{mg} / \mathrm{kg}$ when compared to control.

In another study Gupta et al reported that Morusin was an active compound isolated from Morus alba showed significant antiepileptic activity in the models of isoniazid(INH) and maximal electroshock seizure test in rats at the dose of 5 and $10 \mathrm{mg} / \mathrm{kg} .{ }^{14}$ The result showed that morusin may act through increasing the GABA levels.

Yamatake et al reported that extracts of mulberry root bark in the dose of $10 \mathrm{mg} / \mathrm{kg}$ significantly decreased the number of deaths on maximal electroshock seizure in mice but did not decrease the duration of tonic hind limb extension significantly. ${ }^{15}$ This study reported that extracts of mulberry root bark had mild inhibitory effect on electroshock, but however their study was done with a low dose i.e., $10 \mathrm{mg} / \mathrm{kg}$ as compared to $400 \mathrm{mg} / \mathrm{kg}$ in this study. This suggest that the different parts of the tree like leaves extract and root bark extract have antiepileptic activity.

\section{CONCLUSION}

As MES is suppressed by drugs that enhance GABA-A receptor-mediated inhibitory neurotransmission the 
probable mechanism of Morus alba to show activity in MES induced convulsion is through GABA-A mediated neurotransmission. The present findings coupled with earlier reports suggest that the bioactive factors present in selected extracts of Morus alba leaves offer neuroprotection thus may be helpful in the treatment of seizure disorders. Further investigation of the mechanism of action of the plant extract, as well as the active substance responsible for its biological actions, is necessary. Pentylenetetrazole is a tetrazole derivative with consistent convulsive effect which acts by antagonizing the inhibitory GABAnergic neurotransmission. PTZ test is used for screening of drugs effective in petitmal epilepsy. Morus alba in the dose of 200 and $400 \mathrm{mg} / \mathrm{kg}$ showed highly significant anti-epileptic activity in the seizures induced by pentylenetetrazole in a dose dependent manner compared to control group $(p<0.001)$, but less significant with standard (sodium valproate) indicating that it has anti- epileptic property.

Gupta et al reported that methanolic extract in high doses $(100 \mathrm{mg} / \mathrm{kg}) \quad$ significantly suppressed PTZ induced convulsions in rats and showed statistically significant anticonvulsant activity in PTZ induced convulsions. ${ }^{13}$ The present study was in accordance with the above stated study with MAE at doses of 200 and $400 \mathrm{mg} / \mathrm{kg}$ when compared to control.

As PTZ acts by antagonizing the inhibitory GABAnergic neurotransmission, MAE may act by enhancement of GABA-A receptor-mediated inhibitory neurotransmission to show significant activity in PTZ induced convulsions. Further investigation of the mechanism of action of the plant extract, as well as the active substance responsible for its biological actions, is necessary and it can be used as add on drug for epilepsy along with standard drugs.

\section{ACKNOWLEDGEMENTS}

I express my gratitude and sincere thanks to Dr. G. Veera Nagi Reddy, Principal, Narayana Medical College for allowing me to avail the college facilities during the present study. I will always remain sympathetic towards all the innocent animals that had to suffer for the completion of my research and also for the betterment of the human society.

Funding: No funding sources Conflict of interest: None declared

Ethical approval: The study was approved by the Institutional Animal Ethics Committee (protocol number 27/2013/NMC, dated 20/12/2013)

\section{REFERENCES}

1. Samleti AS, Sharma N, Tambole RD, Dhobale SK. Traditional herbs used in treatment of epileptic seizures. Int J Pharma Chem Sci. 2012;1(3):1411-8.
2. McNamara JO. Pharmacotherapy of the epilepsies, In Laurence Brunton editor. Goodman \& Gilman's. The Pharmacological Basis of Therapeutics. 12th ed. New York, NY: McGraw Hill Companies; 2011: 583.

3. Devi B, Sharma N, Kumar D, Jeet K. Morus alba linn: a phytopharmacological review, Int J Pharm Pharma Sci. 2013;5(2):14-8.

4. Doi K, Kojima T, Makino M, Kimura Y, Fujimoto Y. Studies on the constituents of the leaves of Morus alba L. Chem Pharm Bull. 2001;49:151-3.

5. Bose PC. Genetic resources of mulberry and utilization. Mysore; CSR and TI; 1989: 183-190.

6. Shahid I, Umer Y, Sirajuddin, Kim WC, Raja AS, Kamal U. Proximate Composition and Antioxidant Potential of Leaves from Three Varieties of Mulberry (Morus sp.) A Comparative Study. Int J Mol Sci. 2012;13:6651-64.

7. Chon SU, Kim YM, Park YJ, Heo BG, Park YS, Gorinstein S. Antioxidant and antiproliferative effects of methanol extracts from raw and fermented parts of mulberry plant (Morus albaL.). Eur Food Res Technol. 2009;230:231-7.

8. Heibatollah K, Nasrin A, Maryam B. Hepatoprotective effect of Morus alba L. In carbon tetrachloride- induced hepatotoxicity in mice. Saudi Pharma J. 2009;17(1).

9. Chung KO, Kim BY, Lee MH, Kim YR, Chung HY, ParkJH et al. In-vitro and in-vivo anti- inflammatory effect of oxyresveratrol from Morus alba L. J Pharm Pharmacol. 2003;55(12):1695-700.

10. Yadav AV, Kawale1 LA, Nade VS. Effect of Morus alba L. (mulberry) leaves on anxiety in mice. Indian $\mathbf{J}$ Pharmacol. 2008;40(1):32-6.

11. Mohammadi J, Naik PR. Evalution of hypoglycemic effect of Morus alba in an animal model, Indian $\mathbf{J}$ Pharmacol. 2008;40:15-8.

12. Gupta SK. Drug screening methods, 2nd edition. New Delhi: Jayapee; 2009: 383-389,401-412.

13. Gupta G, Afzal M, Rani S, Verma R, Candaswamy M, Anwar F. Anticonvulsant activity of Morus alba and its effect on brain gamma aminobutyric acid level in rats. Pharmacog Res. 2014;6:188-9.

14. Gupta G, Dua K, Kazmi I, Anwar F. Anticonvulsant activity of Morusin isolated from Morus alba, Modulation of GABA receptor. Biomed Aging Pathol. 2013;4(1):29-32.

15. Yamatake. Y, Shibata M, Nagai M. Pharmacological studies on Root Bark of Mulberry Tree (Morus alba), Japan. J Pharmacol. 1976;26:461-9.

Cite this article as: Rayam S, Kudagi BL, Sufyan UM, Buchineni M, Pathapati RM. Assessment of Morus alba (Mulberry) leaves extract for anticonvulsant property in rats. Int J Basic Clin Pharmacol 2019;8:520-3. 